\title{
Uterine Contraction Interval
}

National Cancer Institute

\section{Source}

National Cancer Institute. Uterine Contraction Interval. NCI Thesaurus. Code C92907.

The time interval between uterine contractions during labor. 